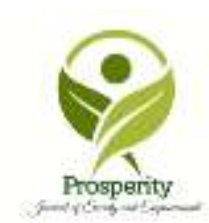

Prosperity: Journal of Society and Empowerment

Vol. 1 No. 1 (June 2021): 15-29

DOI: 10.21580/prosperity.2021.1.1.7843

\title{
Culinary in Petik Sari Tradition: Meanings and Values along Society Empowerment
}

\author{
Ahmad Zainuri \\ UIN Sunan Kalijaga Yogyakarta, Indonesia \\ ahmadsultanzain1986@gmail.com
}

\begin{abstract}
Tradition is a local activity with mystical nuances, a religion that has been around for a long time and flows in people's lives. The purpose of this article is to explain a cultural community tradition with its culinary variety. Community empowerment (rewang) which is represented as a joint movement to build traditions and empower together. In this paper the author uses the socioreligious study method using a phenomenological approach and theoretical framework. This approach is relevant to this study because phenomenology can analyze it to an event that some people might consider normal. However, there are hundreds of meanings that can be expressed in each blade of the Nusantara's culinary offerings. It is also embedded in the attitude of empowering women, mothers or the entire community so that they can share recipes and cook in a tradition. There is also an educational, spiritual value that will be embedded in every culinary dish of the Nusantara. The theory that I want to use is Auguste Comte's theory of evolution and Acculturation from Koentowijoyo's point of view. Typical foods in traditions that hold meaning include Jenang, Tumpeng, Takir, and Ingkung Chicken meat. Community empowerment is the key to the preservation of Various traditional culinary delights with their economic, cultural, and historical aspects.
\end{abstract}

Keywords: Tradition, Culinary, Empowered

\section{ABSTRAK}

Tradisi merupakan sebuah aktivitas lokal dengan nuansa mistis dan religi yang sejak lampau sudah ada dan mengalir dalam kehidupan masyarakat. Tujuan artikel ini akan menjelaskan tentang sebuah tradisi masyarakat kultural dengan ragam kulinernya. Sebuah pemberdayaan masyarakat dalam bergotong royong (rewang) yang terrepresentasi menjadi gerakan bersama untuk membangun tradisi dan berdaya bersama. Dalam tulisan ini penulis menggunakan metode kajian sosial keagamaan dengan menggunakan pendekatan fenomenologi. Pendekatan ini relevan dengan kajian ini, karena fenomenologi mampu menganalisisnya hingga pada sebuah kejadian yang mungkin dianggap sebagian 
orang itu lumrah. Namun, ada ratusan makna yang bisa diungkap dalam setiap bilah sajian kuliner Nusantara. Pun tersemat dengan sikap pemberdayaan perempuan, ibu-ibu atau seluruh masyarakat agar bisa berbagi resep dan memasak dalam sebuah tradisi tersebut. Ada pula nilai edukasi, spiritual yang hendak tertanam dalam setiap sajian kuliner Nusantara. Teori yang hendak penulis gunakan ialah teori Evolusi oleh Aguste Comte dan Akulturasi dari pandangan Koentowijoyo. Makanan khas dalam tradisi yang menyimpan akan makna, antara lain Jenang, Tumpeng, Takir, dan Ayam Ingkung. Pemberdayaan masyarakat menjadi kunci dalam terus terlestarinya sebuah ragam kuliner tradisi dengan berbagai aspek ekonomi, budaya dan sejarah.

Kata kunci: Tradisi, Kuliner, Berdaya

\section{INTRODUCTION}

Recording Mulfi to Yuliyani stated that tradition comes from Latin traditio which means continued. In the simplest definition, tradition can be interpreted as something that has been done for a long time and is part of the life of a community group. Tradition is an image of human attitudes and behaviour that has been processed for a long time and is carried out from generation to generation from ancestors (Yuliani, 2010). Van Paursen explained that tradition is the process of inheriting or passing on norms, customs, and property rules (Van Paursen, 1998). Piotr explains that the most basic thing about tradition is the existence of information that is passed from generation to generation, both written and often oral because without this information, a tradition can become extinct (Sztompka, 1997).

Tradition cannot be separated from a meaning that is often spoken on the Javanese people tongue, namely slametan. The author will discuss in detail about the slametan in a tradition or at a community celebration. That attitude is an attitude that is sure and aware that the values in Javanese culture are really strong and elastic in facing every challenge of the times. The origin of the slametan tradition has existed since the time of the Javanese ancestors (Syam, 2007). Suyono explained that the offerings are intended for the Almighty, apostles, guardians, gods, angels, powers contained in a scholar or respected, demons, ghosts, spirits, and others, to please. This offering is referred to as Selamatan (Suyono, 2007). Pius explained that tradition is a habit that is carried out from generation to generation (A. Partanto, 2001).

At the centre of the entire Javanese religious system, there is a small, simple, formal, undramatic and almost secretive ceremony. Slametan (sometimes called Kenduri) slametan is the Javanese version of what is perhaps the most common religious ceremony in the world. A slametan can be held in response to almost any event that is to be commemorated, redeemed or sanctified. birth, marriage, witchcraft, death, housewarming, nightmares, harvesting, changing names, opening factories, illness, pleading with village guardian spirits, circumcision and the start of a political meeting can all lead to a slametan. Most slametans are held at night, immediately after sunset and the maghrib prayer is performed by those who practice it, sometimes also in the afternoon or precisely after the Asr prayer. If the event involves a change of name, harvest or circumcision, the host will invite a religious expert to determine auspicious days according to the calculation of the Javanese calendar system (Geertz, 1989). 
One of them is how the traditional activities of an event can provide a good social atmosphere, so that many residents, neighbours come to cook and help, that is the meaning of the social side that was not thought of before. The activities are packed full of crowds, beautiful and harmonious so that it requires a lot of persons to do things in the kitchen. With the arrival of neighbors, family and friends, the food menu is also varied, there are opor, stir fry, chicken and others, there are also snacks, such as putu cake, kucur, mendhut, nogosari cake and others. It is an arrangement in an event in society when there is a celebration. Food that is often an offering to welcome a tradition is certainly served on certain days and it is not uncommon for those who make it, it can be called traditional food.

Sometimes the food is served when there is a sacred family celebration, or in a palace. Traditional food does not only dwell on a tradition, but also on the location of the spices and the peculiarities of the food which is legendary in a certain area and maybe even nationally. According to Agnes Siwi in Jordana that traditional food or local culinary is a type of food that is closely related to an area and is passed down from generation to generation as part of the tradition. Local food typical of regions in Indonesia has existed for a long time and still survives to this day so it is highly valued as a cultural heritage. The recipes used have also been passed down from generation to generation, even the way of cooking is still preserving the old way. Although there have been modifications or variations, the main ingredients and cooking procedures have not changed. Because they are part of an area, these traditional foods are very easy to find and even become tourism icons in those places, such as pempek from Palembang, Gudeg from Yogyakarta, and the Solo Selat from Solo (Siwi Purwaning Tyas, 2017).

According to Guerrero (Siwi Purwaning Tyas, 2017) traditional food or local culinary is food products that are often consumed by a group of people or served in celebrations and at certain times, passed down from generation to generation, made according to recipes passed down from generation to generation, made without or with a little engineering., and has certain characteristics that distinguish it from other regional cuisines. Traditional food means that it can be said as a local identity, because of its existence which is part of the community culture, such as certain procedures in processing food ingredients, its role in community culture and celebration procedures, as well as recipes that are maintained from generation to generation (Siwi Purwaning Tyas, 2017).

We strongly emphasise is on the discussion of culinary. Because the author wants to reveal a traditional snack that may no longer be touched, even though it is touched but is not as popular as before. So that the point of emphasis in this article is on the culinary, the meaning and value contained in it or better known for its philosophical meaning. The author also uses the study of the Petik Pari tradition approach as an embodiment and intermediary of how these traditional snacks or snacks can also exist. For example Tumpeng, Ingkung Chicken, Kenduri, Jenang and others. The food is made none other than when there is a celebration or indeed there is a ritual at that time. However, now anyone could make it, but not much either. So that this philosophical value becomes a focus on the local tradition. However, community involvement by empowering each other to make these dishes, mutual cooperation is also the meaning and value of this culinary and tradition. 


\section{METHODS}

\subsection{Phenomenological Approach}

The phenomenological approach seeks to study and understand various religious phenomena as they are by allowing the manifestations of religious experience to speak for themselves. This approach emerged at the end of the 20th century, mainly due to the influence of the philosophy developed by Edmund Husserl. Phenomenology was born and applied in the study of religion as a scientific research method that tries to align with theological approaches. The focus of attention on religious phenomenology is only focused on searching for the essence or substance of a meaning and fundamental structure of human religious experience. The phenomenological approach can be interpreted as efforts made to give birth to a separate discipline that is objective with its methodology. The point is that phenomenology is an approach that tries to combine the objective and subjective properties that exist in every religious scholar (Noviyani, 2019).

A phenomenologist can at least put aside all theories, presuppositions, and prejudices to understand phenomena as they are. This seems to be in line with Leopold van Ranke's idea that we must reveal what happened (Rozali, 2020). For this reason, Husserl proposes a step that must be taken to achieve the essence of the phenomenon, so that Husserl has a method in formulating a phenomenon, namely the epoch method. The word epoch comes from a Greek word that means, "to postpone a decision" or "to empty oneself of a certain belief". Phenomena that appear in consciousness are completely natural without being interfered with by observers (Thohir \& Sahidin, 2019).

Phenomenological inquiry (method of inquiry) begins with silence. Silence is an action to reveal the meaning of something being studied. What phenomenologists emphasize is the subjective aspect of people's behaviour. They try to enter into the conceptual world of the subjects they study in such a way that they understand what and how an understanding is developed by them around events in their daily lives. Phenomenologists believe that in living things there are various ways to interpret the experience through interactions with other people and that it is our understanding of experience that shapes reality (Rozali, 2020). While related to religion, phenomenology is a development movement in thought and research in which researchers try to understand humans and classify phenomena specifically, including religious phenomena. The phenomenological approach that the author uses is more specific to religious phenomenology. Religious phenomenology is oriented to descriptive factual, which is not concerned with evaluative assessments but describes precisely and accurately a religious phenomenon such as rituals, symbols, worship (individual or ceremonial), theology (oral or written), personal that is considered sacred, art, etc.

Two things characterize the phenomenological approach. First, it can be said that phenomenology is a method for understanding other people's religions in a neutral perspective and using the preferences of the person concerned to try to reconstruct in and according to the experiences of these other people. In other words, it is a kind of action that puts aside thinking from one's point of view (epoch), and the researcher tries to use an approach and bring to life the experiences of others, stand up and use the views of others (Fikri Zuhriyah, 2011).

Luluk continued, explaining that the most important thing in the religious phenomenology approach is what is experienced by religious adherents, what is felt, said and done and how the 
experience is meaningful to him. The truth of the study of phenomenology is an explanation of the meaning of ceremonies, rituals, ceremonies, doctrines or social relations for and in the diversity of actors. The phenomenological approach is to construct a taxonomic design to classify phenomena of religious, cultural, and even epoche communities. The phenomenological task after collecting as much data as possible is to look for categories that will reveal similarities to the group. This activity is essentially looking for a structure in religious experience for the broader principles that appear in shaping human religiosity as a whole.

\subsection{Theoretical Framework}

The theoretical study is something that will support the elaboration of a variable using the theoretical side to provide answers to research problems that have been formulated. In this case, we use the theoretical side as follows.

First, acculturation. According to the KBBI (Indonesian Dictionary), acculturation is defined as the absorption that occurs by an individual or a group of people towards certain characteristics of the culture of another group as a result of contact or from the interaction of the two cultural groups. Meanwhile, according to Koentjraningrat in his introduction to anthropology, acculturation is defined as a social process that arises when a group of people with a certain culture are confronted with elements of a foreign culture in such a way that the elements of the foreign culture are gradually accepted into their own culture. without causing the loss of the cultural personality itself (Koentjaraningrat, 2015). Likewise, with acculturation that occurs in the tradition of picking pari salvation, local culture that has existed for a long time meets new cultures, namely Hindu culture and Islamic culture. In this case, the new culture continues to influence the already established culture, but in reality, both cultures enjoy the fusion of these cultures in a tradition of picking pari salvation without losing the local culture.

Second, evolution theory. According to the theory of evolution, social change will always change from simple things to become more complex, from ordinary life to more advanced life (Chabibi, 2019). This theory argues that all groups of people have a fixed direction that all groups of people follow. One of the theorists belonging to this group, Auguste Comte, formulated the evolutionary development of society into three stages, namely:

\section{Theological stage}

At this stage, humans believe in the existence of supernatural powers created by these natural substances or powers that come from humans. this state is characterized by human belief in the power of amulets. This period is divided into three sub-stages, namely: fetishism is the dominant form of thought in primitive society, including the belief that all objects have their life force (spirits); polytheism is an assumption that arises because there are forces that regulate life or natural phenomena (gods or supernatural beings). At this stage, it can be said as the stage of the development of the theological system; monotheism is the belief in a God that is replaced by a singular one. where only the sovereign God can rule this universe.

\section{Metaphysical stage}

This stage is a transition phase to the stage between the theological stage to the positivistic stage. At this stage, humans assume that the mind is not a creation of supernatural substances. But 
it is a creation of the abstract power of time which is truly considered to exist which is inherent in all human beings and is capable of creating all phenomena.

\section{Positivistic stage}

At this stage, the human mind is no longer looking for absolute ideas, which originally predestined the universe and are the causes of phenomena, but the human mind begins to look for the laws that determine phenomena, namely to find a series of relationships that do not change and have similarities. (Chabibi, 2019). From the point of view of the theory of evolution put forward by Comte, the implementation of the pari picking tradition goes through three stages: at the theological stage, the community believes that the implementation of pari picking salvation before harvest will have a good impact on their rice plants; at the metaphysical stage of religion, even though the community still carries out the picking pari house salvation, they do not fully believe in the meaning of the pari picking salvation.

\section{RESULTS AND DISCUSSION}

\subsection{Javanese Culinary Offerings in the Pari Picking Tradition}

Tradisi The pari picking tradition is one of the traditions that is still carried out by some people, the majority of whom work as farmers. This Pari Picking tradition, those who still apply it a tradition before harvest to give an offering to Dewi Sri and her ancestors. Slametan is carried out on the land to be worked on. People assume that the rice plant will be guarded by the spirit of Dewi Sri (Geertz, 2013). Therefore, some people have a habit of respecting Dewi Sri at all stages of the rice planting process to processing the results. Pari picking is often associated with gratitude for the goodness of Dewi Sri who is considered the Goddess of Rice (Makin, 2016). In Javanese myth, she is mentioned as the first person to plant rice in Java. Slametan also means a meal ceremony consisting of offerings, symbolic food, official welcome and prayer (Beatty, 2011). Sometimes offerings are also available when there is a village clean (Rizkiawan \& Wahini, 2017).

The slametan ceremony by placing offerings is intended to get good agricultural results. Traditional ceremonies, for the Javanese people, contain high philosophical values (Frederick Kamsiadi, 2013). Before cultivating the rice fields, the Javanese will perform a ceremony by giving offerings on the cultivated land, this salvation is also intended for those who are instrumental in helping in cultivating their land. Before harvesting rice, each farmer will make offerings and tumpeng containing food near his rice fields to be enjoyed by his assistants. In this offering, the request is addressed to Dewi Sri to provide an abundant harvest, and thanks for protecting rice from all diseases and pests.

Uborampe Uborampe is a set of food, drink, all equipment and tools regarding the items needed and needed in a ritual. Uborampe is used to refer to the composition of the items or objects needed to make a package of offerings. For example, the offerings for the slametan uborampe are young coconut, incense, setaman flowers, tumpeng, ingkung and others. According to Anita and Hanif Uborampe, equipment is needed/used in the salvation event in the village clean ceremony tradition as well as in other traditions. There are many kinds of Uborampe, such as yellow rice, ingkung, and flowers, and so on. In this case, it is women who are tasked to fulfil it because women are considered as someone more skilled or capable in cooking or related to other kitchen 
problems. In addition to acting as a producer or provider of uborampe (Setyowati \& Hanif, 2013). The following is the composition of uborampe in stingrays.

\section{Cok Bakal}

According to Wiranoto, Cok Bakal is an offering made to get salvation and blessings from God and to avoid disaster. Cok will usually contain (Wiranoto, 2018); (1) Village chicken eggs are a symbol of wiji dadi (seeds). Usually, the Javanese people think that the egg is the origin of human life (Sholikhin, 2010). (2) Setaman flower. This setaman flower is a symbol so that every human being can make his own or family name like the smell of flowers. The setaman flowers used are red roses, ylang white roses, kanthil and jasmine (Wintala A, 2019). (3) Keleman aims to prevent the plants from being disturbed by pests. The glue used is cassava, arrowroot, uwi, canna, gothe and sweet potato. (4) Comb and mirror. This uborampe equipment is specifically used for agricultural safety. Usually, combs and mirrors are combined with cold powder and parem. This Uborampe is intended for Dewi Sri, the ruler of agriculture to always be beautiful, fragrant and attractive (Giri MC, 2010). (5) Empon-empon. Empon-empon or spices that are usually used in offerings include: garlic, red onion, turmeric, temulawak, ginger, kencur, laos and cinnamon. All the above ingredients are placed in a container made of banana leaves called takir. This offering is a special offering that is non-negotiable in the pari picking ritual ceremony.

\section{Takir}

Before carrying out the harvest, the first thing to be prepared is to put offerings in every corner of the rice fields, people call it takir. Takir is a form of creation made from banana leaves. Takir is formed by folding both sides of a banana leaf by balancing both sides and then stabbed with a stick that has been sharpened at each corner so that takir can stand and when used as a container the contents will not spill.

Kenduri is a tradition that has been going on for decades, maybe even hundreds of years. This tradition still takes place, especially in the villages. The essence is the same, only the terms may be different. In essence, kenduri is a social mechanism to care for and maintain togetherness so that the ideals that have been created since all of these are reaffirmed. Kenduri is also a tool of social control to maintain the movement and direction of the ideals that have been fought for together. Within the framework of this social mechanism, kenduri accommodates and represents many interests. This feast can establish the meaning of friendship and make relations between communities more harmonious, increase mutual cooperation and in establishing cooperation in society (Arifianto et al., 2018).

At first the sko kenduri event was a traditional ceremony that was routinely carried out every year, the time of its implementation was after the harvest period. However, as time goes by and the needs of the community are increasing, the sko kenduri event has changed the implementation time to once every 5 years. In accordance with the traditional expression which says "one buffalo and one hundred rice" which must be spent for this ceremony which is certainly difficult for the community to work on. The kenduri sko ceremony consists of a series of activities starting with a traditional village meeting, art night, the coronation of indigenous people and reading of original manuscripts and cleaning of heirlooms Based on observations in the field, the traditional meeting 
was attended by traditional leaders, religious scholars and intellectuals known as Tigo Furnace Sarangan and community members. The purpose of the meeting is to deliberation to choose who should be given a title, to discuss problems in the community such as juvenile delinquency, which prohibits adat to be violated, sanctions for violators and to make new agreements related to the interests of the community. Deliberations select community members who will hold customary titles by first examining who the parents are who have died or have not died but must be dismissed because they are old and old. The deliberation also discussed when the implementation would be, how to find costs and the formation of the event organizing committee (Helida, 2016).

\section{Chicken Ingkung}

Indonesia is famous for its many culinary delights that have their philosophical meaning in their dishes, one of which is ayam ingkung, which is a dish that comes from chicken cooked whole. Ingkung comes from the word inggalo njungkung or prostrate (Giri MC, 2010). Ingkung chicken is usually served in a large tray as a dish in various traditional events and Javanese celebrations. Ayam ingkung has a philosophy that cannot be ignored in Javanese culture. The chicken is a symbol of gratitude and enjoyment gained in the world because of the power of God. Only delicious chicken is the offering, which is why ingkung chicken is presented in its whole form and beautifully arranged. Chicken is a good form of prayer for humans to be able to imitate the behaviour of chickens. The chicken does not devour all the food given to it but only chooses to eat which is good and not to eat which is bad. Man is expected to be able to choose which is good and which name is bad and must be left in his life ("History-And-Philosophy-Chicken-Ingkung-Lauk-Utama-Tumpeng-Dalam-AdatJawa," 2020).

Purwanti (Harun) explains ingkung is a chicken that is cooked whole with its neck and legs tied and how to cook it by roasting it over a fire. Furthermore, he explained that ingkung chicken is a Javanese chicken that is cooked whole and given spices, usually also added coconut milk which symbolizes human beings from birth when they are babies have no sin is still pure. Ingkung also has meaning as human submission to God Almighty (Novita Lisa \& Susilo, 2021). Ibn Wahid explained that ingkung has a meaning or philosophy contained in it, such as the position of a rooster crouching has the meaning of prostration, meditation, surrender. At the root of the word, Ingaccording to the Javanese means "Ingsung" or which means me and "Ngkung" or Manekung which means praying sincerely. So, sometimes Ingkung ii is also presented in an event in which there is a prayer for thanksgiving to God (Ibnu Wachid, 2020). There is also what means a whole chicken as the position of a woman sitting upright as if praying. Ingkung has a philosophy with his chicken lambing, that is, chicken if the fed is not directly eaten, but selected so that humans are expected to be able to choose which is good and which is bad, humans must be able to sort and choose (Wahab, 2017).

\section{Tumpeng}

Tumpeng or buceng is one of the mandatory dishes that are often present in rituals or salvation events. Food made of rice in the shape of a cone with chillies shaped like a flower at the end usually served on a bamboo tray (tampah) with a variety of traditional side dishes such as eggs, chicken, tempeh, urap-urap and many more. Tumpeng is symbolized as the meaning of fertility and well- 
being, having a cone shape resembling a mountain is interpreted as a human desire to obtain true glory, while chilli is intended to symbolize the fire of courage ("Philosophical Meaning Meaning of Javanese Cok Bakal, Javanese offerings or offerings and meaning of Ubo Rampe," 2019).

Zein expressed that there are many different meanings for the values contained in Tumpeng and believed by the community: first, the cone shape on the Tumpeng symbolizes life as well as humans and nature. In Javanese philosophy, humans and nature are considered as manifestations of the state of God, or as the aura (emanation) of God; second, he cone shape on the Tumpeng symbolizes the relationship of humans as creatures to the forces, gods, or God as the creator substance, by placing them in the highest position that controls all humans. According to Ng. Suyatno, the triangular shape on the Tumpeng also symbolizes the three highest powers (trimurti), namely Lord Shiva as ruler and destroyer of nature, Lord Brahma as a creator of the universe, and Lord Vishnu as preserver and protector of the universe; third, the unity of rice grains that are compressed to form a cone illustrates the unity of human hopes and aspirations collectively to the forces, gods, or God, namely asking for salvation before, during, and afterlife; fourth, the triangular shape on Tumpeng means that the life process takes place in three stages, namely purwa-madya-wusana (beginningmiddle-end) or from the state of "being", then "becoming", and ending in "nothing"; and fifth, the cone shape on the Tumpeng also illustrates the level of inner perfection that is difficult for every human being to reach, which is the higher you go, the fewer grains of rice you can occupy (Zein EdDally, 2019).

\section{Jenang-jenangan}

Jenang Jenang or porridge is Uborampe which is rarely left in every Javanese ritual. Jenang is one of the typical foods of the Javanese population. This food has been attached since the time of the Hindu-Buddhist kingdoms and Walisongo. They interpret jenang as a symbol of rejection of balance, so they hope that there will be safety in every event held. Foods made from white rice or glutinous rice are often served as complementary foods in baby birthday celebrations, death events and much more. Jenang is a processed food in the form of thick porridge made of flour or other ingredients (Baehaqie, 2014). In Petik Pari there are four types of jenang served. (1) White Jenang is uborampe made from rice flour. (2) Jenang abang is uborampe made from rice flour mixed with brown sugar so that it is red. (3) Jenang sengkala atau sengkolo. This jenang is red and white and a manifestation of the merging of white jenang and jenang abang as the origin of human creation. This porridge is someone's hope that is addressed to siblings to always get salvation. (4) Jenang abang putih or old jenang. This porridge resembles jenang sengkolo, what distinguishes it from this jenang is where the old jenang is placed between white jenang and jenang abang. The meaning of jenang sepuh as a symbol of equality of roles between men and women (Giri M.C., 2010).

The existence of jenang among the community is a typical snack made of white rice and glutinous rice, often present as a complementary food at various events such as wedding celebrations, congratulations for pregnant women, congratulations for newborns, event for the dead and many other traditional events. as well as religious. All kinds of events can never be separated from the presence of jenang and this food is believed to arise from the creativity of the local community. Jenang is not just a typical food favored by Javanese people. More than that, jenang turns out to have philosophical and symbols that are believed by the Javanese. Aside from 
being grateful to Him, jenang is also used as a symbol of prayer, unity, hope, and the spirit of the Javanese people. The types of symbols between jenang are different, considering that there are several types of jenang that are famous on the island of Java.

After all the offerings are prepared, the offerings are below to the edge of the rice fields that are ready to harvest. After that someone or a traditional leader (a trusted person) will burn incense and burn coconut skin (sepet) then read prayers. At the end of the takir ritual containing cok will be placed in every corner of the rice field and then it ends with distributing food and side dishes to the neighbors. Offerings or offerings in Javanese terms, after they are finished, they are placed in the rice fields. And each region has different ways and rules and in essence they are the same, namely as a form of gratitude to God who has given time and opportunity for farmers to harvest their rice as a form of rice granary and a primary need for humans.

\subsection{The Meaning and Value of Traditional Culinary in Tradition}

Culinary becomes a very beautiful dish when approaching an event or indeed becomes the speciality of each family or tribal community. Culinary has indeed become a side where it is rich in implied and explicit meanings and some spices that are typical of the archipelago are spices that never fade with age. That is what later became a characteristic as a typical Indonesian food with a variety of styles, spices and historical stories behind it. There is a value contained in these kinds of foods into a preparation that proves that there are so many different foods and culinary delights of the archipelago. Of course, processed foods and culinary delights are not only served directly, some are one of the mainstay menus in a stall, but there is one meaning contained in a food and culinary that should later become one of the historical studies in studying the culinary studies of the archipelago. One of them is a Petik Pari tradition or the other, it presents a tradition for Javanese farming communities in accommodating agricultural products into local traditions with special meals as offerings of gods and humans.

Basically, local Indonesian people are looking for a side where there are values contained in every activity, especially regarding ancestral traditions. These meanings and values have become a very, very solid glue in the local race of Indonesian people from the past until now. Unfortunately, there are some community groups who do not agree with the rituals carried out by a number of these communities because the form of relying on local traditions is brought to the religious level. However, we have dismissed all of that as an old discourse and let us all open it in one sheet in building harmony and tolerance among all religious, ethnic and cultural people that exist on this motherland of Indonesia.

Typical Javanese or other foods are often served with different nuances, such as tumpeng when there is a Mauludan event, kenduri during a slametan, kupatan when there is a birth or Eid al-Fitr and many more. This level has entered the portion where culture or tradition begins to intersect and come into contact with religion. However, some of these intersectional groups do not need to be debated, especially regarding food, why should you serve offerings, feasts and others, no need to review it again, most importantly there is one meaning that unintentionally gives a good social side to fellow human beings.

There are several meanings and values contained in a traditional food and culinary which is a requirement for a noble value in human life with God. In general, they are all people who still use 
food during a celebration with a variety of food names and meanings, they are still thick in a current of tradition and culture. However, it is basically an adhesive rope between humans and forms a positive social side with each other as well.

\subsection{Community Empowerment}

In this explanation, community empowerment is very necessary and has a very positive effect on sustainability in a tradition, especially the manufacture of ancient snacks, Javanese culinary specialties. With the togetherness of the community, both young and old, mutual cooperation or the Javanese term is rewang in making these traditional snacks. although today it may not be considered lost, but in the next era that the value of this tradition will not be inherited again, especially the recipe and how it is made and served. In this increasingly sophisticated era, by just opening Youtube all the recipes and procedures are already there, even people who previously couldn't cook, by only watching 1-2 hours of videos now they can.

The meaning emphasized here is not a praxis in the formation of snacks, but the value of togetherness, the meaning of togetherness in mutual cooperation, which is an added value in the culture of life. Both villages and cities, at a glance today they are all the same. The practice is the same as working together to form an empowered community for mutual progress, especially for the village or region. Advocacy for the community, especially mothers who like the culinary world, has become a common progress in empowering villages to be tradition-friendly. So that cultural traditions, culinary, cultural arts can be synergistic with each other and can create a performance in a show with mutual empowerment. For example, there are theatrical performances, art artists, music and on the other hand, mothers can highlight the results of their joint gifts, namely selling ancient snacks, typical village cuisine or special souvenirs.

Included in the tradition of Petik Pari, an activity carried out together, parading a large tumpeng, or takir carrying various traditional colors and other traditional symbols. A big event, also invites the wider community to witness the rituality of the pari methic procession. So what is waiting for is eating together by eating rice tumpeng or takir (rice feast) with the community, both local and outsiders who are watching the Petik Pari ritual. For example, this is a village with such multi customs and cultures, so that it can be sovereignly turned into a traditional village. Especially the cohesiveness of the community in building togetherness, from a tradition of Petik Pari, from the start of the ceremony, the ritual, even the symbol, becomes an image that can be an attraction to continue to build culture.

Empowerment will appear, when the community is compact, together in knitting to create beauty for each other. Including making culinary, ancient snacks originating from all foods from the Java region or the archipelago, by jointly making them in the Petik Pari tradition or other traditions, this can stimulate the spirit to awaken that is so important and valuable when a tradition is colored with ancient culinary or snacks. . Do not let awareness rise, when it has been taken and claimed by other regions or even other countries, only to realize that it is a tradition inherited from ancestors, ancestors, even though it is in the form of food. Including maintaining the recipe, the values and meanings implied in it are so sublime.

In a theoretical and conceptual sense, the author interprets the concept of the blackmail of society. Poverty reduction activities and efforts to expand employment opportunities as a step towards reducing unemployment can be done by using a society's impoverishment approach. The 
empowerment of society is one of the efforts to enhance the well-being and independence of society in meeting the needs of life by making society actively involved in various activities to address the problems of poverty. In line with this, Theresa in the Ratio explains that exploitation is an attempt to satisfy the needs of individuals, groups and communities in order to have the ability to make choices and control their environment to fulfill their desires, including their availability to resources.The connection to his work, his social activities and so on (Kumalasari, 2015).

The society's empowerment activity is essentially how to create a persuasion that doesn't force society. So it is only right that in the course of the blackmailing of the people be given the freedom to independently meet their needs. In the self-determination activities. is a basic principle in the field of social work or social welfare. This idea may be interpreted as a call to target groups to determine for themselves what they should do to deal with the problems they face. Further, this idea aims to give target groups full consciousness and power in shaping their future. It is only right that poverty alleviation activities in society should use the principle of self-determination, because with this principle the activities carried out to address poverty should be adapted to the abilities of the society. So that in its activities the public is more active, not just accepting help from the government to solve its problems.

The information above has provided an introduction to the analysis of activities in the culinaryization procession in the culture of the Petik Pari tradition. This can indeed evoke one of the axis of cultural and tourist destinations. There is no doubt that a culinary and tradition combined with a unique food order, this unique area provides its own point of view. In addition, there is an edutourism value contained in it, namely that with the existence of community empowerment, especially mothers, hope is placed on how to process these traditional foods and can pass them on to the next generation and can share recipes to continue to be preserved. In addition to the cultural side, the economic side indirectly becomes a conductor to generate a culinary-based creative economy with local traditions, indirectly a location where it will become one of the village tours with the preservation of tradition and culinary. As stated above because there is a purpose of "Self Determination". is a basic principle in the field of social work (gotong royong) and social welfare.

\section{CONCLUSION}

In essence, in a big event with beautiful conditions, religious pluralism, cultural pluralism, ethnicity and tradition, do not then make it a divisive reason. The reason is that local traditions are acts of religious deviance, even though with the existence of these local traditions the community can be united, just and harmonious. As long as all these activities are filled with positive activities, don't just judge everything from the outside. The process of spreading Islam Wali Songo is without violence, everything is melted with harmony. The plurality of society is a reality to be grateful for, and that is Indonesia. The tradition of tumpeng, feast, chicken ingkung and jenang are foods or culinary delights that are present during certain celebrations and are associated with beautiful meanings. In essence, they are also present in an event that is full of solemnity without any blame and aims to build harmony among the people.

The meanings and values contained in building a harmony in the variety of traditions, cultures and religions in Indonesia must be realized through a beautiful activity. One of them is a tradition by 
showing and entertaining a variety of traditional culinary dishes. In this case, it implies a meaning of respect for ancestors and praying for the sustenance that can be harvested which is prayed to God. The cuisine that is served is the hallmark of a grand event. By bringing neighbors, relatives to participate in cooking when an event takes place. Traditional foods such as tumpeng, kenduri, chicken ingkung and jenang are not served unless there is a big event or activity that takes up a lot of crowds. The food, becomes a meaning in the life of the person who is organizing it and can be distributed to those who are being invited, including Picking Pari and other traditions. Every traditional food contains a condition of meaning and value that is wise and wise. All of that from a meaning that is implied from the ancestors to their children and grandchildren, with the elaboration of Islamic nuances or wrapped in other religions.

That is a list of the pari picking tradition with a unique culinary offering of the archipelago which is meaningful and requires a moral teaching in human life. The meaning of culinary, traditional food that has existed since the early archipelago (animism-dynamism) to the new Islamic civilization, is a moral offering and wrapped in the meaning of making every behavior a cultural norm. The legendary spices that have become a special dish and served on a special day make Indonesian food a requirement for meaning and full of traditional values with the aim of building a simple life by continuing to preserve tradition. Tradition becomes a wise habit by wrapping harmony, uniting mankind with a variety of cultural decorations by serving culinary as the end of a celebration and tradition. That is the meaning of every tradition, that food is the final dish and a dish that unites people from all walks of life with typical Indonesian-style food with the condition of meaning.

The last but not least, the meaning of empowerment in the wider community, apart from that they are empowered to cook, empowered to witness rituals. However, they also get a series of meanings to empower each other. Both fathers and mothers, in this tradition, are mutually involved, to cook Tumpeng rice, Ingkung Chicken, Jenang is the power of mothers, for activities to prepare tents, carnival events when Petik Pari, it's the father's job, so that community empowerment feels strong and solidarity is evident. What is also expected is that a tradition by then creating each other's special dishes can continue and become a tradition. Don't lose it if it can become an agenda that continues every year. Although the current of change in symbolism must exist, because the core and meaning contained in the values in Petik Pari are what are important, namely the value of togetherness to make special dishes, mutual cooperation. That's why it's important, archive records of a recipe like making Ingkung, Tumpeng and the noise when making it, that's the point, especially when the event is carried out by involving many people.

\section{REFERENCES}

A. Partanto, P. (2001). Kamus IImiah Populer. Surabaya: Arkola.

Arifianto, D., Nurman, \& Fitria Dewi, S. (2018). Nilai-Nilai Moral dan Sosial dalam Penyelenggaraan Kenduri Sudah Tuai di Desa Kumun Mudik Kota Sungai Penuh. Journal of Civic Education, 1(3), 246. https://doi.org/10.24036/jce.v1i3.213.

Baehaqie, L. (2014). Jenang Mancawarna sebagai Simbol Multikulturalisme Masyarakat Jawa. Komunitas: Jurnal Research \& Learning in Sociology and Anthropology, 6(1), 183. http://dx.doi.org/10.15294/komunitas.v6i1.2952. 
Beatty, A. (2011). Variasi Agama di Jawa; Suatu Pendekatan Antropologi. Jakarta: PT Raja Grafindo Persada.

Chabibi, M. (2019). Hukum Tiga Tahap Auguste Comte dan Konstribusinya Terhadap Kajian Sosiologi Dakwah. Nalar: Jurnal Peradaban dan Pemikiran Islam, 3(1), 18. https://doi.org/10.23971/njppi.v3i1.1191.

Fikri Zuhriyah, L. (2011). Metode dan Pendekatan dalam Studi Islam: Pembacaan atas Pemikiran Charles J. Adams. Islamica, 2(1), 34. https://doi.org/10.15642/islamica.2007.2.1.27-45.

Frederick Kamsiadi, B. (2013). Istilah-Istilah yang Digunakan pada Acara Ritual Petik Pari oleh Masyarakat Jawa di Desa Sumberpucung, Kabupaten Malang (Kajian Etnolinguistik). Publika Budaya: Jurnal IImu Budaya dan Media, 1(1), 67.

Geertz, C. (1989). Abangan, Santri, Priyayi, dalam Masyarakat Jawa. Jakarta: Pustaka Jaya.

Geertz, C. (2013). Agama Jawa: Abangan, Santri, Priyayi dalam Kebudayaan Jawa. Depok: Komunitas Bambu.

Giri MC, W. (2010). Sajen dan Ritual Orang Jawa. Yogyakarta: Narasi.

Helida, A. (2016). Perhelatan Kenduri Sko sebagai Sebuah Pesan Kebudayaan Masyarakat Kerinci di Taman Nasional Kerinci Seblat. Jurnal Masyarakat, Kebudayaan dan Politik, 29(1), 40. http://dx.doi.org/10.20473/mkp.V29I12016.34-43.

Ibnu Wachid, Moch. (2020). Akulturasi dan Revitalisasi Tradisi Syukuran Ingkungan Malam Jum'at Wage dan Tahlilan Adat Istiadat Hindu Jawa dengan Islam di Musholla al- Barokah Dsn. Kandangan Ds. Sugihwaras Kec. Prambon. Academia.Edu, 2.

Koentjaraningrat. (2015). Pengantar Ilmu Antropologi. Jakarta: PT Rineka Cipta.

Kumalasari, R. (2015). Evaluasi Implementasi Program Nasional Pemberdayaan Masyarakat Mandiri Pedesaan (Pnpm-Mp) Bidang Simpan Pinjam Bagi Kelompok Perempuan (Studi Kasus pada Masyarakat Desa Tanjungrejo Kecamatan Wuluhan Kabupaten Jember) [Skripsi]. Universitas Jember.

Makin, A. (2016). Keragaman dan Perbedaan: Budaya dan Agama dalam Lintas Sejarah Manusia. Yogyakarta: Suka Press.

Makna Filosofis Arti Cok Bakal Jawa, Sesajen Jawa atau Sesaji dan Arti Ubo Rampe. (2019). [Homepage]. Www.Narasiinspirasi.Com. https://www.narasiinspirasi.com/2019/08/filosoficok-bakal-sesajen-sesaji-dan.html.

Novita Lisa, H., \& Susilo, Y. (2021). Makna Simbolis Tradisi Nyanggring Ing Desa Tlemang Kecamatan Ngimbang Kabupaten Lamongan (Tintingan Folklor). Baradha: Jurnal Pengembangan Bahasa, Sastra dan Budaya Jawa, 17(1), 13.

Noviyani, I. (2019). Pendekatan Studi Islam "Pendekatan Fenomenologi dalam Kajian Islam. AtTadbir: Jurnal Manajemen Pendidikan Islam, 3(1), 44. https://doi.org/10.3454/attadbir.v3i1.3412.

Rizkiawan, I., \& Wahini, M. (2017). Faktor-Faktor yang Mempengaruhi Persepsi Masyarakat Tentang Makna Sesajen pada Upacara Bersih Desa. Jurnal Boga, 5(2), 13.

Rozali, M. (2020). Metodologi Studi Islam dalam Perspektif Multidisiplin Keilmuan. Depok: Rajawali Buana Pustaka. 
Sejarah-dan-filosofi-ayam-ingkung-lauk-utama-tumpeng-dalam-adat-jawa,. (2020). [Homepage]. Www.Fimela.Com. https://www.fimela.com/lifestyle- relationship/read/3870155/sejarahdan-filosofi-ayam-ingkung-lauk-utama-tumpeng-dalam-adat-jawa.

Setyowati, A., \& Hanif, M. (2013). Peran Perempuan dalam Tradisi Upacara Bersih Desa: Studi Kasus di Desa Kiringan Kecamatan Takeran Kabupaten Magetan [Makalah]. IKIP PGRI.

Sholikhin, M. (2010). Ritual dan Tradisi Islam Jawa. Yogyakarta: Narasi.

Siwi Purwaning Tyas, A. (2017). Identifikasi Kuliner Lokal Indonesia dalam Pembelajaran Bahasa Inggris. Jurnal Pariwisata Terapan, 1(1), 3. https://doi.org/10.22146/jpt.24970.

Suyono, R. P. (2007). Dunia Mistik Orang Jawa. LKiS.

Syam, N. (2007). Madzhab-Madzhab Antropologi. LKiS.

Sztompka, P. (1997). Kebudayaan Kemanusiaan dan Lingkungan Hidup. Hasanuddin University Press.

Thohir, A., \& Sahidin, A. (2019). , Filsafat Sejarah Profetik, Spekulatif dan Kritis. Jakarta: Prenada Media Group.

Van Paursen, C. A. (1998). Strategi Kebudayaan. Yogyakarta: Kanisius.

Wahab, F. (2017). Nilai-Nilai Pendidikan Islam yang Terdapat di Dalam Simbol-Simbol Sesaji pada Upacara Selametan di Desa Sayutan Kecamatan Parang Kabupaten Magetan [Skripsi]. Universitas Muhammadiyah.

Wintala A, S. (2019). Sejarah Agama Jawa. Yogyakarta: Araska.

Wiranoto. (2018). Cok Bakal Sesaji Jawa. Surabaya: CV Jakad Publishing.

Yuliani, E. (2010). Makna Tradisi "Selamatan Petik Pari" Sebagai Wujud Nilai-Nilai Religius Masyarakat Desa Petungsewu Kecamatan Wagir Kabupaten Malang [Skripsi]. Univeritas Negeri Malang.

Zein Ed- Dally, M. (2019). Makanan Tumpeng dalam Tradisi Bancakan (Studi Gastronomi Pada Masyarakat Jawa Islam) [Skripsi]. UIN Sunan Ampel. 